\title{
Modifications in the Chemical and Mineralogical Composition of Compacted Mature Residual Soil Submitted to the Percolation of Acidic Leachates
}

\author{
E.P. Korf, P.D.M. Prietto, A.A. Silveira, C. Ulsen, N.C. Consoli, L. Bragagnolo
}

\begin{abstract}
The main goal of this paper is to evaluate the chemical and mineralogical composition of a compacted residual clay soil with the addition of Portland cement and under different compaction conditions to observe and to understand the chemical and mineralogical changes that these structures undergo. Results of chemical and mineralogical composition of compacted specimens in different unit weights $\left(14.5,15.0\right.$ and $\left.15.5 \mathrm{kN} / \mathrm{m}^{3}\right)$ and percolated by different concentrations of aqueous solution of sulfuric acid ( 0,1 and $2 \%$ ), under the application of a vertical load of $280 \mathrm{kPa}$. The modifications in the chemical and mineralogical composition of the specimens were evaluated by the combination of X-ray fluorescence (XRF), X-ray diffraction (XRD), scanning electron microscopy (SEM) and thermogravimetry with differential thermal analysis and exploratory differential calorimetry (TG/DTG/DSC). The results have shown that the percolation of $\mathrm{H}_{2} \mathrm{SO}_{4}$ resulted in changes in the $\mathrm{Fe}_{2} \mathrm{O}_{3}, \mathrm{CaO}$ and $\mathrm{SO}_{3}$ contents for different cement contents and for specific weights; it was also evidenced dissolution of $\mathrm{Fe}_{2} \mathrm{O}_{3}$ in the upper layers and the formation of $\mathrm{Ca}$ and $\mathrm{S}$ compounds in the lower layers. No changes in mineralogy and soil morphology were found out.
\end{abstract}

Keywords: compact residual soil, acid attack, cement content, specific weight, containment barriers, chemical and mineralogical composition

\section{Introduction}

Industrial and mining processes are responsible for environmental impacts resulting from the production of contaminated waste, mainly by acidic compounds. These compounds can affect geotechnical structures, such as barriers of compacted soil and can promote changes in micro and macrostructural scales, such as the increase of hydraulic conductivity, reduction of reactive power and resistance of these structures (Broderick \& Daniel, 1990; Favaretti et al., 1994; Hueckel et al., 1997; Knop et al., 2008; Rubinos et al., 2016). When in contact with soil particles, acidic compounds can promote complex reactions that result in changes in the mineral and physicochemical composition of the soil and, consequently, changes in its properties (Šucha et al., 2002).

One of the alternatives that has been evaluated in the literature refers to the usage of soil-cement mixtures as a material component of containment barriers (Fall et al., 2009; Forcelini et al., 2016; Helson et al., 2018; Iravanian
\& Bilsel, 2016; Joshi et al., 2010). However, few of these studies present a chemical, mineralogical and microstructural evaluation of this type of structure under the action of aggressive chemical compounds, as well as their effects on the macrostructural response, aiming to improve the knowledge about the behavior of containment structures and to understand the interaction between contaminants, soil particles and cement (Lloret et al., 2003; Romero, 2013; Romero \& Simms, 2009).

Therefore, the paper's novelty stems from the understanding of physicochemical alterations, which is essential to the search for an ideal condition for the design of compacted soil-cement barriers, in order to ensure structural durability and chemical/physical containment.

In this context, this work aims to evaluate the chemical and mineralogical composition of a compacted residual clay soil with the addition of Portland cement and under different compaction conditions to observe and to understand the chemical and mineralogical changes that these structures undergo. A better understanding of these phe-

Eduardo Pavan Korf, D.Sc., Associate Professor, Universidade Federal da Fronteira Sul, Programa de Pós-Graduação em Ciência e Tecnologia Ambiental, ERS 135, km 72, n. 200, 99700-970, Erechim, RS, Brazil. e-mail: eduardo.korf@uffs.edu.br.

Pedro Domingos Marques Prietto, D.Sc., Associate Professor, Universidade de Passo Fundo, Programa de Pós-Graduação em Engenharia Civil e Ambiental, BR 285, km 292, 99052-900, Passo Fundo, RS, Brazil. e-mail: pdmp@upf.br.

Adriana Augustin Silveira, D.Sc., Professor, Universidade de Passo Fundo, Faculdade de Engenharia, BR 285, km 292, 99052-900, Passo Fundo, RS, Brazil. e-mail: aas@upf.br.

Carina Ulsen, D.Sc., Professor, Universidade de São Paulo, Laboratório de Caracterização Tecnológica, Departmento de Engenharia de Minas e Petróleo, Prof. Mello Moraes Avenue, 05508-030, Butantã, São Paulo, SP, Brazil. e-mail: carina@1ct.poli.usp.br.

Nilo Cesar Consoli, D.Sc., Full Professor, Universidade Federal do Rio Grande do Sul, Departamento de Engenharia Civil, Osvaldo Aranha Avenue, 99, $3^{\circ}$ andar, 90035-190, Porto Alegre, RS, Brazil. e-mail: consoli@ufrgs.br.

Lucimara Bragagnolo, M.Sc. Student, Universidade Federal da Fronteira Sul, Programa de Pós Graduação em Ciência e Tecnologia Ambiental, ERS 135, km 72, n. 200, 99700-970, Erechim, RS, Brazil. e-mail: lucimarabragagnolo@estudante.uffs.edu.com.

Submitted on April 17, 2019; Final Acceptance on January 29, 2020; Discussion open until August 31, 2020.

DOI: $10.28927 /$ SR.431159 
nomena will allow the improvement of techniques for the use of soil-cement mixtures in impermeable barriers subjected to vertical static loading and to the percolation of acidic leachates.

\section{Materials and Methods}

The experimental procedure has involved the following steps:

(a) Sampling of residual clay soil from the experimental field of Geotechnics of the University of Passo Fundo (UPF), located in Passo Fundo city - RS, Southern Brazil;

(b) The soil samples collected were characterized by X-ray fluorescence analysis (XRF), Loss on ignition (LOI) and mineralogical composition by $\mathrm{X}$-ray diffractometry (XRD) using the powder method. It was also determined the organic matter content and $\mathrm{pH}$ by the method described by Tedesco et al. (1995), and the clay content (ABNT, 2016);

(c) Physical-mechanical characterization and analysis of the chemical composition of Portland cement CPVARI:

I. The physical-mechanical characterization was performed through unconfined axial tests at 3, 7, 14 and 28 days of curing, particle density and initial and final time of handle according to the norms (ABNT, 1997, 2001, 2003).

II. The chemical characterization was performed by $\mathrm{XRF}$, followed by loss on ignition. The mineralogical analysis was conducted by XRD, using the powder method.

(d) Molding of cylindrical specimens with addition of different cement contents and under different dry specific compacting weights, followed by percolation with acidic aqueous solution;

(e) Section and preparation of remolded and not remolded samples of percolated specimens;

(f) Characterization of percolated specimens in chemical, mineralogical and morphological composition by scanning electron microscopy (SEM), XRD, XRF and thermogravimetry with differential thermal analysis and differential scanning calorimetry (TG / DTG / DSC).

To define the variables to be considered in the percolation tests, a $2 \mathrm{k}$ factorial experimental design $(\mathrm{k}=2)$ was performed, with the addition of central points, with the variables cement content added to the soil (0 and $2 \%)$ and dry unit weight. The values of dry unit weight and molding moisture content corresponding to the energy of the Normal Proctor type were used as reference. Thus, dry unit weight of 14.5 and $15.5 \mathrm{kN} / \mathrm{m}^{3}$ with $26 \%$ molding moisture content were used.

The experimental planning resulted in 4 factorial points with addition of 4 more central points ( $1 \%$ cement addition and dry unit weight of $15.0 \mathrm{kN} / \mathrm{m}^{3}$ ). The 8 combi- nations resulting from this planning were divided into 2 blocks, each one with percolation of aqueous solution with volumetric concentration of $0 \%$ and $2 \%$ of sulfuric acid. This planning allows the evaluation of the behavior and mathematical modelling of a response surface and the identification of the existence of non-linearity (Montgomery, 2001).

Thus, for each combination of cement content and dry compaction specific gravity, specimens of $7 \mathrm{~cm}$ in diameter by $6 \mathrm{~cm}$ in height were subjected to long-term percolation tests (from 30 to 70 days), with and without percolation of sulfuric acid solution. A hydraulic gradient of 8.33 and a vertical pressure of $280 \mathrm{kPa}$ were applied to represent the disposal of $15 \mathrm{~m}$ rejects on the barrier with unit weight of $18.6 \mathrm{kN} / \mathrm{m}^{3}$, according to literature data (Bedin, 2010).

The test specimens were then sectioned in three layers (referred to as top, middle and bottom, considering downflow) from which an undisturbed and a remolded sample were extracted per layer to be subjected to chemical and mineralogical analysis. The undisturbed sample was segmented in a prismatic format with dimensions of approximately $2.0 \quad 0.7 \quad 0.7 \mathrm{~cm}$ and identified by layer $(\mathrm{S}=$ upper, $\mathrm{M}=$ medium, $\mathrm{I}=$ lower). The layers were identified from measurements, dividing the specimen into 3 equally spaced pieces with the aid of a pachymeter. This set of samples was dried in an oven up to $45{ }^{\circ} \mathrm{C}$ and duly preserved from humidity. For scanning electron microscope (SEM) analysis, the samples were prepared in polished sections by the impregnation with epoxy-liquid resin, followed by sanding, polishing and gold plating. It was also prepared $50 \mathrm{~g}$ of remolded sample from each specimen for performing XRD, XRF and TG / DTG / DSC analyses. To do so, these samples were dried at $105^{\circ} \mathrm{C}$ and deagglomerated to obtain a product with less than $0.044 \mathrm{~mm}$ granulation.

The SEM analysis was performed on the undisturbed samples sectioned from each test specimen in a high-resolution scanning electron microscope (W or Lab6), manufactured by Shimadzu, model Vega 3. The analyses were performed in the Scientific and Technological Park of the University of Passo Fundo. The following analytical conditions were used in the analyses: secondary electrons mode with magnification of above 1000 times, electron beam of nominal resolution of $3.0 \mathrm{~nm}$, voltage of $20 \mathrm{kV}$ and vacuum of $10^{-4} \mathrm{~Pa}$, which allowed the morphological evaluation of the samples and microstructure of the particles. The XRD analyses were performed in an X-ray diffractometer, manufactured by PANalytical, model EMPYREAN, with detector X'Celerator, copper tube and by the powder method. The analytical conditions were: angle intervals $2 \theta$ from 3 to $70^{\circ}$, time lapses of $10 \mathrm{~s}$ and $\mathrm{Cu} \mathrm{K} \alpha$ radiation. The identification of the crystalline phases was obtained by comparing the diffractogram of the sample with the PDF-2 databases of the ICDD International Centre for Diffraction Data (2003) and PAN-ICSD PANalytical Inorganic Crystal Structure Database (2007). 
The XRF analyses were performed on an X-ray fluorescence spectrometer, manufactured by PANalytical, Axios Max model with X-ray tube (Rhodium $4 \mathrm{kV}$ ) at the Mineral and Rock Analysis Laboratory of the Federal University of Paraná (UFPR), using semiquantitative method with detection above $0.1 \%$ and scanning time of approximately $6 \mathrm{~min}$ in pulverized and pressed samples. The loss on ignition was determined at $1000{ }^{\circ} \mathrm{C}$ for $2 \mathrm{~h}$. Finally, the TG/DTG/DSC analyses were performed at the laboratory of minerals and rocks analysis at the Federal University of Paraná (UFPR), in a thermogravimetry equipment manufactured by Netzsch, model STA 409 PC/PG with heating from $25^{\circ} \mathrm{C}$ to $1000{ }^{\circ} \mathrm{C}$ and heating rate of $10{ }^{\circ} \mathrm{C} / \mathrm{min}$ and atmosphere of $\mathrm{N}_{2}-60 \mathrm{~mL} / \mathrm{min}$.

\section{Results and Discussion}

\subsection{Soil and cement}

The studied soil is a mature residual soil from basalt and its pedological classification according to Streck et al. (2008) is as an oxisol.

According to the carried out characterization, this soil has low organic matter content $(<0.8 \%)$, high clay content $(68 \%)$ and acid $\mathrm{pH}(\mathrm{pH} 5.5)$. X-ray diffraction analysis (Fig. 4) and its chemical composition (Table 1) shows the presence of kaolinite as a source of clay (also confirmed by the aluminum content), as well as the presence of hematite $\left(\mathrm{Fe}_{2} \mathrm{O}_{3}\right.$ content of $\left.11.7 \%\right)$ and quartz. These characteristics are conditioned with good capacity for use of this soil as a base material for compacted barriers.

As for cement, significant amounts of $\mathrm{SiO}_{2}(18 \%)$ and $\mathrm{CaO}(66.2 \%)$ identified by XRF were observed (Table 2). Through the cement physical-mechanical characterization, it was observed that the resistance and the initial and final handle times, $40 \mathrm{MPa}, 160$ and $265 \mathrm{~min}$, respectively, agreed with the values proposed by the related standards (ABNT, 1991), setting initial time greater or equal to $60 \mathrm{~min}$ and the final one less than or equal to $600 \mathrm{~min}$.

\subsection{Chemical and mineralogical composition}

The chemical composition of the tested samples indicates variations in the iron oxide $\left(\mathrm{Fe}_{2} \mathrm{O}_{3}\right)$, calcium oxide $(\mathrm{CaO})$ and sulfuric oxide $\left(\mathrm{SO}_{3}\right)$, in the test specimens submitted to acid percolation and under different values of cement content and specific weight.

The main effects of the cement content on the $\mathrm{CaO}$ and $\mathrm{SO}_{3}$ contents were classified as significant by the variance analysis $(\mathrm{p}<0.05)$ through ANOVA (analysis of vari-
Table 1 - Soil chemical characterization (XRF) and LOI.

\begin{tabular}{lccc}
\hline Oxide & Content $(\%)$ & Element & Content $(\%)$ \\
\hline $\mathrm{SiO}_{2}$ & 47.9 & $\mathrm{Si}$ & 22.4 \\
$\mathrm{Fe}_{2} \mathrm{O}_{3}$ & 11.7 & $\mathrm{Fe}$ & 8.2 \\
$\mathrm{Al}_{2} \mathrm{O}_{3}$ & 26.6 & $\mathrm{Al}$ & 14.1 \\
$\mathrm{CaO}$ & $<0.1$ & $\mathrm{Ca}$ & $<0.1$ \\
$\mathrm{TiO}_{2}$ & 1.7 & $\mathrm{Ti}$ & 1.0 \\
$\mathrm{~K}_{2} \mathrm{O}$ & 0.4 & $\mathrm{~K}$ & 0.3 \\
$\mathrm{ZrO}_{2}$ & 0.1 & $\mathrm{Zr}$ & $<0.1$ \\
$\mathrm{SO}_{3}$ & $<0.1$ & $\mathrm{~S}$ & $<0.1$ \\
$\mathrm{MgO}$ & 0.4 & $\mathrm{Mg}$ & 0.2 \\
$\mathrm{P}_{2} \mathrm{O}_{5}$ & 0.1 & $\mathrm{P}$ & $<0.1$ \\
$\mathrm{MnO}$ & $<0.1$ & $\mathrm{Mn}$ & $<0.1$ \\
$\mathrm{Na}_{2} \mathrm{O}$ & $<0.1$ & $\mathrm{Na}$ & $<0.1$ \\
$\mathrm{~V}_{2} \mathrm{O}_{5}$ & $<0.1$ & $\mathrm{~V}$ & $<0.1$ \\
$\mathrm{LOI}\left(1.000{ }^{\circ} \mathrm{C}\right)$ & 10.9 & $\mathrm{O}$ & 50.6 \\
& & $\mathrm{C}$ & 3.0 \\
\hline
\end{tabular}

ance). However, the specific weight variable and the interaction between both variables did not reveal a significant influence on the compound contents in the samples, as presented in Table 3. It was also verified that the cement content significantly interfered in the contents of $\mathrm{CaO}$ in all the layers of the samples, for both percolated by acid and not percolated ones ( $\mathrm{p}<0.05$ for all this samples). In relation to $\mathrm{SO}_{3}$, the influence of the cement content was only observed for the samples after the percolation test $(\mathrm{p}<0.05)$. Such behavior indicates a possible interaction between $\mathrm{CaO}$ and $\mathrm{SO}_{3}$ compounds, since the $\mathrm{P}$ values for $\mathrm{CaO}$ after percolation of sulfuric acid are higher than before. In addition, it indicates reactions with the percolated agent itself, with possible formation of $\mathrm{Ca}$ and $\mathrm{S}$ compounds.

In relation to $\mathrm{Fe}_{2} \mathrm{O}_{3}$, although the values did not reach the significance level of $5 \%$, there was a significant decrease of the $\mathrm{P}$ values between the percolated and non-percolated samples by sulfuric acid, which shows that there was an acid attack to this phase of iron oxides and solubilisation. Such behavior is more pronounced in relation to the unit weight variable, which is related to the variation of the number of voids and, consequently, it makes the passage of the percolating agent difficult. The same occurs in $\mathrm{SiO}_{2}$ contents, although the $\mathrm{P}$ values are not so significant $(p>0.05)$. For $\mathrm{Al}_{2} \mathrm{O}_{3}$, the percolation of sulfuric acid re-

Table 2 - Chemical composition of Portland cement CPV-ARI.

\begin{tabular}{ccccccccccc}
\hline \multicolumn{1}{c}{ Content $(\%)$} & & \multicolumn{2}{c}{ LOI } & \multicolumn{2}{c}{ Insoluble residue } \\
\cline { 1 - 6 } $\mathrm{SiO}_{2}$ & $\mathrm{Fe}_{2} \mathrm{O}_{3}$ & $\mathrm{Al}_{2} \mathrm{O}_{3}$ & $\mathrm{CaO}$ & $\mathrm{TiO}_{2}$ & $\mathrm{~K}_{2} \mathrm{O}$ & $\mathrm{SO}_{3}$ & $\mathrm{MgO}$ & $\left(1.000{ }^{\circ} \mathrm{C}\right)(\%)$ & $(\%)$ \\
\hline 18.0 & 2.68 & 4.19 & 66.2 & 0.28 & 0.8 & 1.79 & 2.43 & 3.58 & 0.7 \\
\hline
\end{tabular}




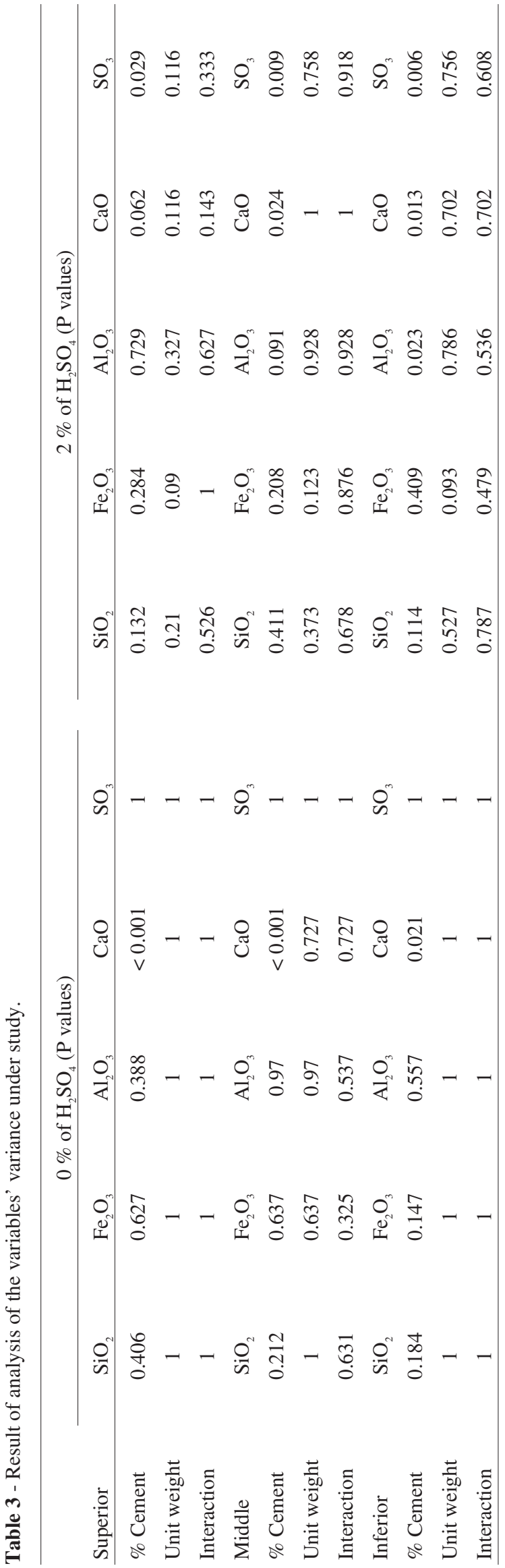

sulted in the decrease of $\mathrm{P}$ values only for the middle and lower layers. The interaction between the two variables was not significant for any of the compounds.

The difference in the $\mathrm{Fe}_{2} \mathrm{O}_{3}$ content between the upper, middle and lower layers (Fig. 1) indicates that the acid attack promotes the dissolution of $\mathrm{Fe}_{2} \mathrm{O}_{3}$ present in the soil, which can cause up to half of the original contents in the upper layers to be reduced (Average from 12 to $7 \%$, Fig. 1a). Wang (2002) proposes that the acid attack in soil-cement mixtures is mainly due to the reaction involving the minerals, since the reaction of the sulphates with the cement is considered of second importance. This justifies the small variations between the $\mathrm{Fe}_{2} \mathrm{O}_{3}$ contents for each layer in relation to the increase of the cement content, as presented in Table 3 , in which the variable cement content did not present significance in all the layers $(\mathrm{p}>0.05)$.

Regarding the unit weight, there was a smaller reduction in the $\mathrm{Fe}_{2} \mathrm{O}_{3}$ content with the increase of the value of this variable, as presented in Fig. 1b. This fact is related to the decrease of the voids due to the increase of the compaction energy, as observed by (Korf et al., 2018), which verified the decrease of the porosity of the specimens after being submitted to the vertical load. This eventually hampered the passage of the sticky agent and prevented the acid attack as well as the degradation of the compound. This relationship can be corroborated by the analysis of variance (Table 3) referring to the unit weight for this compound. The $\mathrm{P}$ values for all the layers are of the order of $10 \%$, indicating a relative part of statistical significance, as well as a significant difference when compared with the samples without percolation of sulfuric acid. For the samples without acid percolation, the studied variables had no influence on the $\mathrm{Fe}_{2} \mathrm{O}_{3}$ content.

Figure 2 shows the $\mathrm{CaO}$ content in relation to the variable cement content for samples with percolation of 0 and $2 \%$ acid solution. No differences were observed between the studied layers for samples without acid percolation. With the analysis of Fig. 2a, the increase of cement content in the soil caused an increase in the $\mathrm{CaO}$ content. This is a result of the hydration reactions and cement hardening with the soil, providing the formation of this compound. This observation justifies the $\mathrm{P}$ values observed for the relation between $\mathrm{CaO}$ and cement contents $(<0.05)$. The samples percolated by sulfuric acid presented variation in the $\mathrm{CaO}$ content between the upper, middle and lower layers. In the upper portion a reduction in the $\mathrm{CaO}$ content was observed in relation to the results of the samples without percolation of sulfuric acid.

While analyzing the Fig. $2 b$, higher concentrations of this compound were observed in the lower layer compared to the upper layers and the non-percolated samples, which is possibly the result of a leaching process in which the $\mathrm{CaO}$ present in the upper layer was transported to the lower regions of the samples due to the acid attack or also because of chemical reactions resulting from chemical attack, thus 

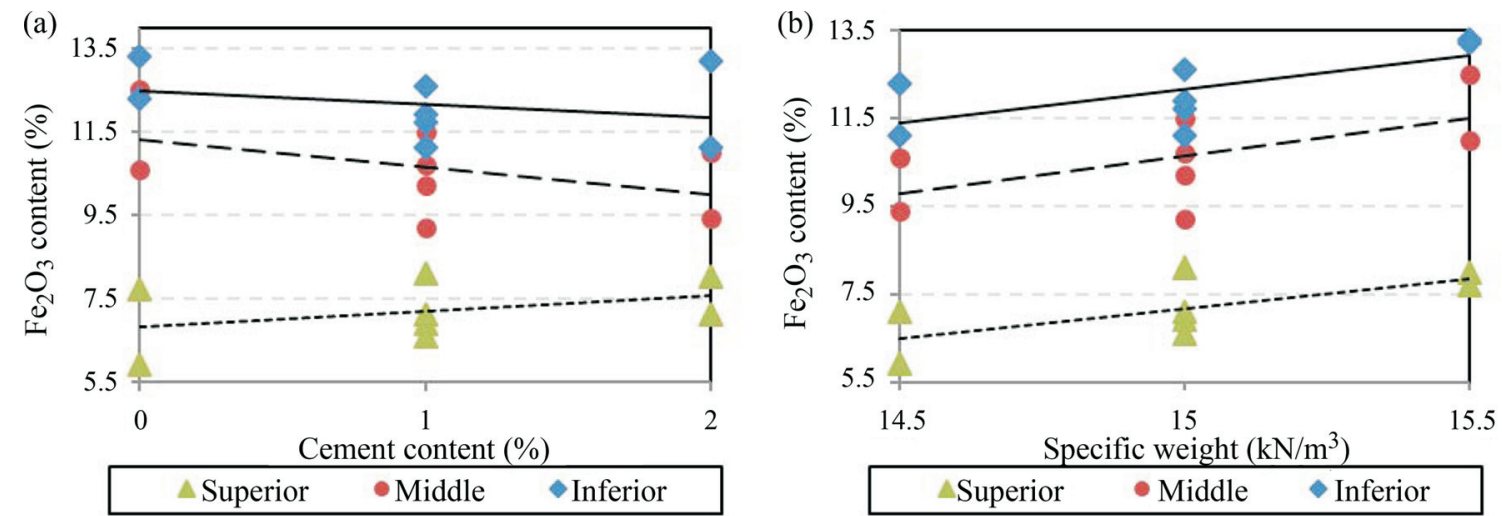

Figure $1-\mathrm{Fe}_{2} \mathrm{O}_{3}$ content for percolated samples per acid solution in relation to (a) cement content and (b) specific gravity.
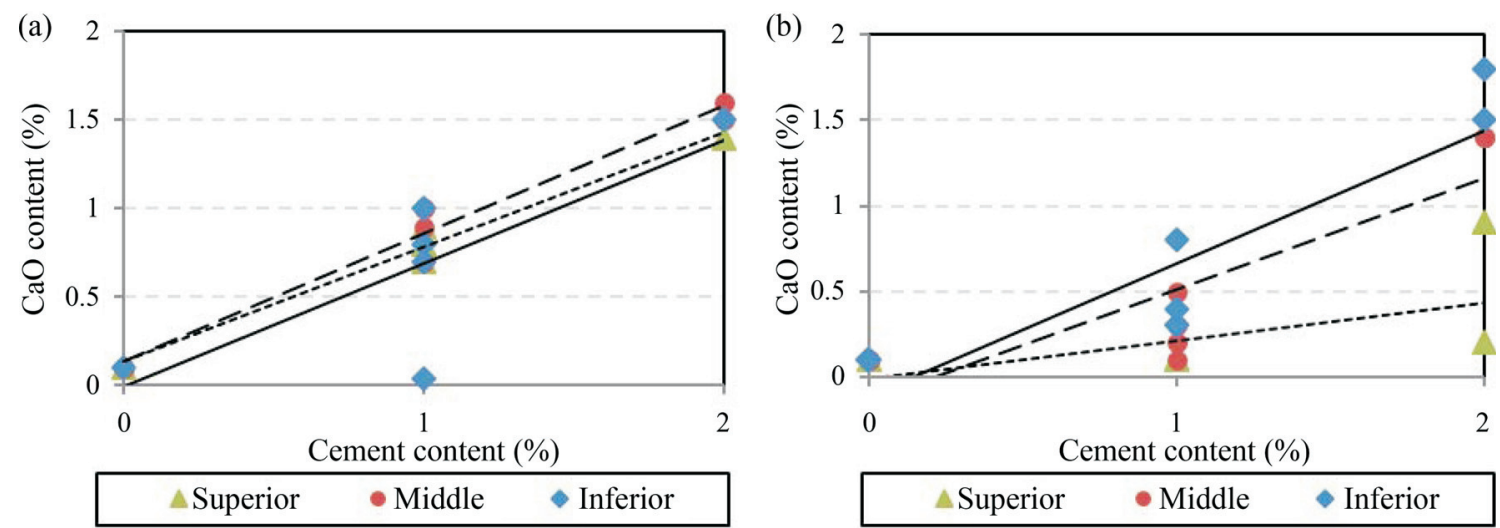

Figure 2 - $\mathrm{CaO}$ content in relation to the variable cement content for (a) samples without percolation - $0 \% \mathrm{H}_{2} \mathrm{SO}_{4}$ and (b) percolated samples - $2 \% \mathrm{H}_{2} \mathrm{SO}_{4}$.

forming new compounds. This behavior was also evidenced by observing the data of the statistical analysis presented in Table 3. The variable cement content for $\mathrm{CaO}$ showed higher significance (lower P values) in the lower layer of percolated samples by sulfuric acid. Since the increase of cement has a direct relation with the increase of $\mathrm{CaO}$ contents, the greater part of the compound has been deposited in the lower layer, resulting in the highest statistical significance observed. The unit weight variable did not influence on the contents of this compound, as corroborated by the statistical analysis (Table 3 ).

Figure 3 shows the behavior of the $\mathrm{SO}_{3}$ content between the analyzed layers of samples percolated by sulfuric acid in relation to the variable cement content. The results show that the middle and lower layers had higher $\mathrm{SO}_{3}$ levels (varying from average values of about $2 \%$ to $4 \%$ ), as well as higher values were observed with increasing cement content. This fact may be related to chemical reactions involving $\mathrm{CaO}$ and the aggressive agent. Likewise, the statistical analysis presented in Table 3 indicated that the highest significance of the variable cement content was in the middle and lower layers (0.009 and 0.006, respectively), which reinforces the evidence presented.

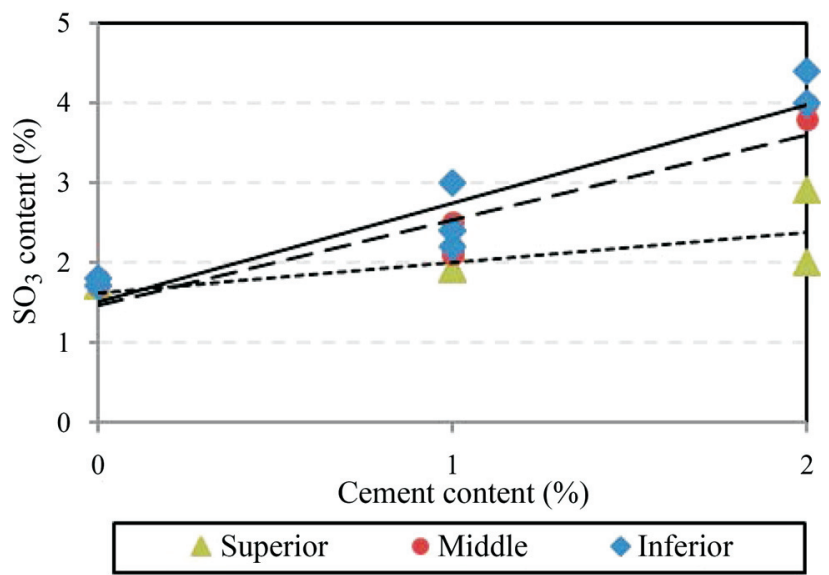

Figure 3 - $\mathrm{SO}_{3}$ content in relation to the variable cement content in samples percolated with $2 \% \mathrm{H}_{2} \mathrm{SO}_{4}$.

The variables studied did not exert influence on the $\mathrm{SO}_{3}$ content in the non-percolated samples (Table 3). Also, the unit weight variable had no influence on the samples submitted to acid leaching.

Figure 4 shows the XRD test data with the mineralogical identification for samples in the crystalline mineralogi- 
cal phase with and without percolation of sulfuric acid. The test specimen selected for XRD analysis, with $0 \%$ cement, was the one that underwent the most significant chemical modifications in the oxide content, evidenced in the XRF analyses. In this case, the mineralogical composition of the material with and without the percolation of $\mathrm{H}_{2} \mathrm{SO}_{4}$, no changes were detected in the crystalline mineralogical composition of the sample and that, according to the analysis, the samples remain with the clay minerals present (kaolinite essentially). This can be related to the low sensitivity of the XRD method for small variations of contents, since the changes in the chemical composition were proved by the chemical analyses.

The results obtained in this work resemble those obtained by MacCarthy et al. (2014) that analyzed the dissolution of hematite and quartz from a lateritic soil, with similar constitution of the samples from this study. MacCarthy et al. (2014) performed batch dissolution tests in a solution of $98 \% \mathrm{H}_{2} \mathrm{SO}_{4}$ and $\mathrm{KNO}_{3}$ at $\mathrm{pH} 1$ and at $25^{\circ} \mathrm{C}$ and verified in their studies that the dissolution occurs more strongly in the oxides phase as iron oxide - hematite than in the quartz. The authors' argument also allows us to infer that the sulfuric acid concentration used in this work was only able to cause chemical changes in the oxide phase present on the surface of the particles, not leading to significant mineralogical changes on the crystalline phase (MacCarthy et al., 2014).

Figure 5 shows the results of the TG / DTG / DSC technique for the test specimens with and without the presence of sulfuric acid, which most evidenced acid attack, respectively. For the acid-percolated sample, the loss of mass was more pronounced in Event 1, featured by pore water dehydration, which is related to the increase in porosity due to acid etching and particulate leaching, allowing greater accumulation of water in the voids and consequent loss of mass due to water dehydration. In the samples percolated by sulfuric acid, it was observed a reduction in the values of the thermal events observed for DSC, possibly due to the acid attack that promoted the reaction of certain compounds, like $\mathrm{Ca}$, or even the dissolution of these ones. This behavior is corroborated by the XRF study in which it is possible to visualize the fall in $\mathrm{CaO}$ contents and a consequent formation of $\mathrm{SO}_{3}$ for samples percolated by sulfuric acid. The major thermal events are shown in Figs. 5a and $5 b$.

Figure 6 shows the scanning electron microscopy image for the sample with $0 \%$ of cement, but with non-percolation $(0 \%)$ and percolation $(2 \%)$ of sulfuric acid. The images, when compared to each other, do not allow the identification of significant modifications in the soil particles morphology. This fact corroborates the mineralogical and chemical analysis results, in which no significant changes were observed in the crystalline clay minerals structure, just only in the oxides fraction. This behavior is also related to the results presented in the XRD analysis, in which no differences were observed between the acid-percolated and acid-non-percolated samples.

Studies in the literature, such as Yang et al. (2013), show that, under extreme conditions of acid $\mathrm{pH}$, soil-cement structures can present a high degree of degradation and even cracks. In this work, only changes in chemical composition were verified, no changes were observed in the crystalline clay minerals structure. No degradation of the microstructure and / or cracking was observed, possibly due to the stiffness of the structure due to the presence of cement, soil type and compaction, as well as a degree of acidity not so high (2\% sulfuric acid), which possibly had to be neutralized due to the presence of cement.

In the same way, Knop et al. (2008), when studying the soil-cement interactions in the presence of sulfuric acid, verified that the addition of cement to the soil is responsible

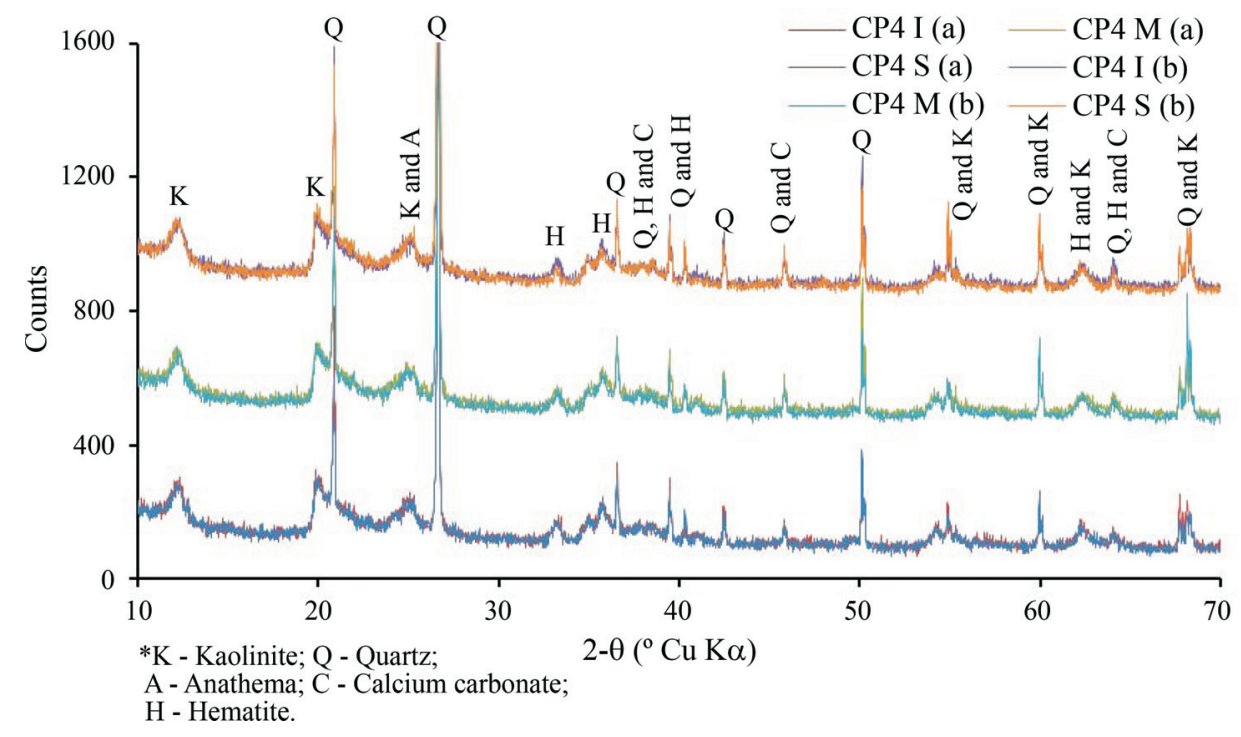

Figure 4 - XRD analysis and mineralogical identification of test specimen (a) $0 \% \mathrm{H}_{2} \mathrm{SO}_{4}$ and (b) $2 \% \mathrm{H}_{2} \mathrm{SO}_{4}$. 

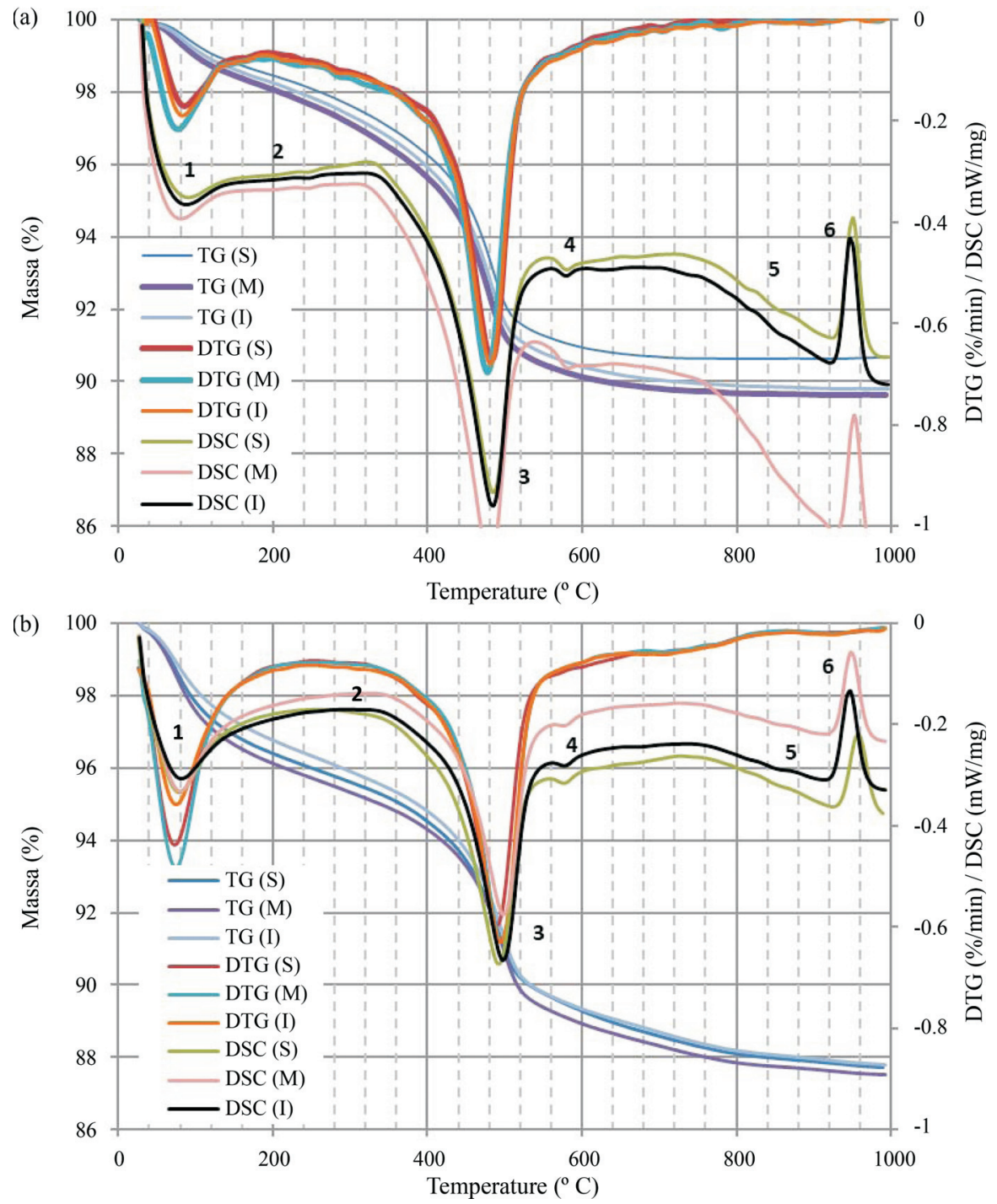

Figure 5 - TG / DTG / DSC Sample analysis (a) $0 \% \mathrm{H}_{2} \mathrm{SO}_{4}$ and (b) $2 \% \mathrm{H}_{2} \mathrm{SO}_{4}$. Thermal events: 1 - Dehydration of pore water; 2 - CaSO (Karathanasis \& Hajek, 1982); 3 - Kaolinite (Critter \& Airoldi, 2006); 4 - Quartz (Bartenfelder \& Karathanasis, 1989); 5 - CaCO (Rowland, 1954; Todor, 1976); 6 - Amorphous aluminum phase crystallization (Kauffman \& Dilling, 1950).

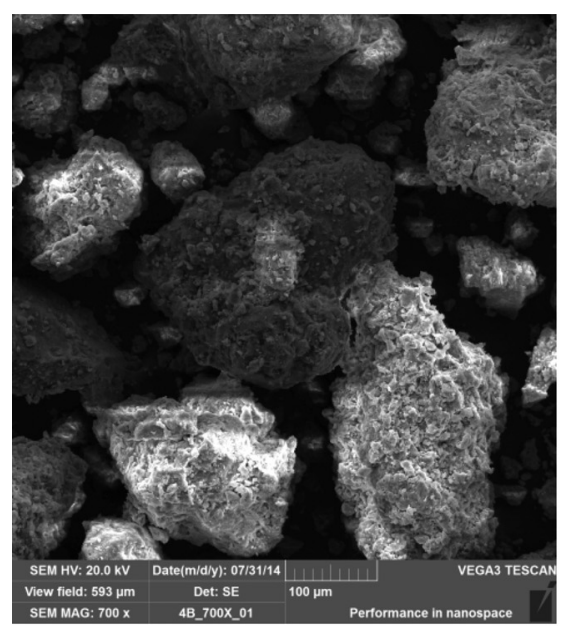

(a)

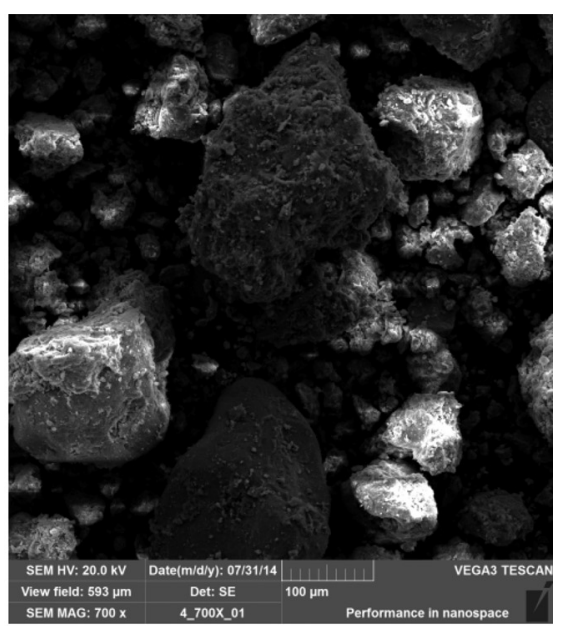

(b)

Figure 6 - Scanning electron microscopy (SEM) microstructure visualization of (a) sample containing $0 \%$ sulfuric acid and (b) sample containing $2 \%$ sulfuric acid. 
for increasing the delay factor and the sulfuric acid distribution coefficient. This means that such mixtures have a greater ability to mitigate the spread of contaminants.

Also, the results presented here are similar to those found by Shaw \& Jim Hendry (2009) in regard to the attack on the clay minerals structures. Shaw \& Jim Hendry (2009) found that the greatest impact occurred on silicon compounds rather than on aluminum ones. Furthermore, these modifications may have occurred in a less expressive way, which makes it difficult to evaluate by certain techniques that do not have high sensitivity, such as X-ray diffraction.

\section{Conclusion}

This work presented the effect of the percolation of acid solutions in mature residual soils with different unit weights and cement contents. Significant changes were observed in the $\mathrm{Fe}_{2} \mathrm{O}_{3}$ present in the soil on the upper layers of samples which indicates that the acid attack promotes the dissolution of this iron oxide, this being mainly this being enhanced by the increasing unit weight, reduction in voids ratio and, consequently, contamination percolation delay. Besides, significant changes were observed in the $\mathrm{CaO}$ and $\mathrm{SO}_{3}$ contents, indicating formation of $\mathrm{Ca}$ and $\mathrm{S}$ compounds in the lower layers of samples, being it also enhanced by higher unit weight and cement content addition. These results were also corroborated by the differential thermal and differential scanning calorimetry analyses (DTG / DSC). No changes were detected in the crystalline mineralogical phase and morphology of the studied soil, observing results with XRD and SEM analyses. Therefore, acidic attack caused changes to minerals as oxides and not in the crystalline structures of mineral clay and quartz.

\section{References}

ABNT (1991). Cimento Portland de alta resistência inicial NBR 5733. Associação Brasileira de Normas Técnicas - ABNT, Rio de Janeiro, RJ, Brazil, 5 p.

ABNT (1997). Cimento Portland - Determinação da resistência à compressão - NBR 7215. Associação Brasileira de Normas Técnicas - ABNT, Rio de Janeiro, RJ, Brazil, 8 p.

ABNT (2001). Cimento Portland e outros materiais em pó Determinação da massa específica - NBR NM 23. Associação Brasileira de Normas Técnicas - ABNT, Rio de Janeiro, RJ, Brazil, 15 p.

ABNT (2003). Cimento Portland - Determinação do tempo de pega - NBR NM 65. Associação Brasileira de Normas Técnicas - ABNT, Rio de Janeiro, RJ, Brazil, 4 p.

ABNT (2016). Solo - Análise Granulométrica - NBR 7181. Associação Brasileira de Normas Ténicas - ABNT, Rio de Janeiro, RJ, Brazil, 12 p.

Bartenfelder, D.C.; Karathanasis, A.D. (1989). A differential scanning calorimetry evaluation of quartz status in geogenic and pedogenic environments. Soil Science Society of America Journal, 53(3):961-967.
Bedin, J. (2010). Estudo do Comportamento Geomecânico de Resíduos de Mineração. Universidade Federal do Rio Grande do Sul. Ph.D. Thesis, Departamento de Engenharia Civil, Universidade Federal da Fronteira Sul, Porto Alegre, 205 p.

Broderick, G.P. \& Daniel, D.E. (1990). Stabilizing compacted clay against chemical attack. Journal of Geotechnical and Geoenvironmental Engineering, 116(10):1549-1567.

Critter, S.A.M. \& Airoldi, C. (2006). Thermal analysis of Brazilian tropical soils originating from different sources. Journal of the Brazilian Chemical Society, 17(7):1250-1258.

Fall, M.; Célestin, J.C. \& Han, F.S. (2009). Suitability of bentonite-paste tailings mixtures as engineering barrier material for mine waste containment facilities. Minerals Engineering, 22(9-10):840-848.

Favaretti, M.; Moraci, N. \& Previatello, P. (1994). Effects of leachate on the hydraulic and mechanical behavior of clay liners. Proc. 1st Congress on Environmental Geotechnics, Alberta, Canada, pp. 221-226.

Forcelini, M.; Garbin, G.R.; Faro, V.P. \& Consoli, N.C. (2016). Mechanical behavior of soil cement blends with Osorio sand. Procedia Engineering, 143(1):75-81.

Helson, O.; Eslami, J.; Beaucour, A.L.; Noumowe, A. \& Gotteland, P. (2018). Hydro-mechanical behaviour of soilcretes through a parametric laboratory study. Construction and Building Materials, 166(1):657-667.

Hueckel, T.; Kaczmarek, M. \& Caramuscio, P. (1997). Theoretical assessment of fabric and permeability changes in clays affected by organic contaminants. Canadian Geotechnical Journal, 34(4):588-603.

ICDD. International Centre for Diffraction Data (2003). PDF-2 database.

Iravanian, A. \& Bilsel, H. (2016). Tensile Strength properties of sand-bentonite mixtures enhanced with cement. Procedia Engineering, 143(1):111-118.

Joshi, K.; Kechavarzi, C.; Sutherland, K.; Ng, M.Y.A.; Soga, K. \& Tedd, P. (2010). Laboratory and in situ tests for long-term hydraulic conductivity of a cement-bentonite cutoff wall. Journal of Geotechnical and Geoenvironmental Engineering, 136(4):562-572.

Karathanasis, A.D. \& Hajek, B.F. (1982). Revised methods for rapid quantitative determination of minerals in soil clays. Soil Science Society of America Journal, 46(1):419-425.

Kauffman, A.J. \& Dilling, D. (1950). Differential thermal curves of certain hydrous and anhydrous minerals, with a description of the apparatus used. Economic Geology, 45(3):222-244.

Knop, A.; VanGulck, J.; Heineck, K.S. \& Consoli, N.C. (2008). Compacted artificially cemented soil-acid leachate contaminant interactions: Breakthrough curves and transport parameters. Journal of Hazardous Materials, 155(1-2):269-276. 
Korf, E.P.; Prietto, P.D.M.; Silveira, A.A.; Ulsen, C. \& Bragagnolo, L. (2018). Porosity changes of compacted soil percolated with acidic leachate. Soils and Rocks, 41(3):369-377.

Lloret, A.; Villar, M.V.; Sanchez, M.; Gens, A.; Pintado, X. \& Alonso, E. (2003). Mechanical behaviour of heavily compacted bentonite under high suction changes. Geotechnique, 53(1):27-40.

MacCarthy, J.; Nosrati, A.; Skinner, W. \& Addai-Mensah, J. (2014). Dissolution and rheological behaviour of hematite and quartz particles in aqueous media at $\mathrm{pH} 1$. Chemical Engineering Research and Design, Institution of Chemical Engineers, 92(11):2509-2522.

Montgomery, D.C. (2001). Design and Analysis of Experiments. John Wiley \& Sons, New York, 790 p.

PANalytical (2007). PAN-ICSD PANalytical Inorganic Crystal Structure Database. Almelo, The Netherlands.

Romero, E. (2013). A microstructural insight into compacted clayey soils and their hydraulic properties. Engineering Geology, 165:3-19.

Romero, E. \& Simms, P.H. (2009). Microstructure investigation in unsaturated soils: A review with special attention to contribution of mercury intrusion porosimetry and environmental scanning electron microscopy. Geotechnical and Geological Engineering, 26(6):705-727.

Rowland, R.A. (1954). Differential thermal analysis of clays and carbonates. Clays and Clay Technology, 169:151-164.

Rubinos, D.A.; Spagnoli, G. \& Barral, M.T. (2016). Chemical and environmental compatibility of red mud liners for hazardous waste containment. International Journal of Environmental Science and Technology, 13(3):773792.

Shaw, S.A. \& Jim Hendry, M. (2009). The impact of sulfuric acid on element migration and mineralogy of compacted clays: $\mathrm{pH} 1.0$ to -3.0. Applied Geochemistry, 24(10):1978-1989.

Streck, E.V.; Kämpf, N.; Klamt, E.; Nascimento, P.C.; Schneider, P.; Giasson, E. \& Pinto, L.F.S. (2008). Solos do Rio Grande do Sul. Emater, Porto Alegre, 222 p.

Šucha, V.; Dubiková, M.; Cambier, P.; Elsass, F. \& Pernes, M. (2002). Effect of acid mine drainage on the mineralogy of a dystric cambisol. Geoderma, 110(3-4):151167.

Tedesco, M.J.; Gianello, C.; Bissani, C. A.; Bohnen, H. \& Volkweiss, S. J. (1995). Análises de solo, plantas e outros materiais: Boletim técnico n ${ }^{\circ} 5$. Departamento de Solos, Faculdade de Agronomia, UFRGS, Porto Alegre, $174 \mathrm{p}$.

Todor, D.N. (1976). Thermal analysis of minerals. Abacus Press, Kent, 256 p.

Wang, L. (2002). Cementituous Stabilization of Soils in the Presence of Sulfate. M.Sc. Dissertation, Department of Civil and Environmental Engineering, Louisiana State University and Agricultural and Mechanical College, Louisiana, $118 \mathrm{p}$.

Yang, Y.; Wang, G.; Xie, S.; Tu, X. \& Huang, X. (2013). Effect of mechanical property of cemented soil under the different $\mathrm{pH}$ value. Applied Clay Science, 79(1):19-24. 